\title{
Spatial distribution pattern of ciliated protozoa in a Mediterranean interstitial environment
}

\author{
G. Santangelo, P. Lucchesi \\ Dipartimento Scienze Ambiente e Territorio, via Volta 4, I-56100 Pisa, Italy
}

\begin{abstract}
The spatial distribution of ciliates in a Mediterranean interstitial community was analysed. During spring and summer ciliates tend to form patches and to stratify reaching their maximal density 3 to $6 \mathrm{~cm}$ below the surface. These patches are a few centimeters wide and deep and, in many cases, show the codominance of several taxa. Together with the distribution of ciliates, that of flagellates and culturable aerobic-heterotrophic bacteria was examined; these microorganisms too show wide variations in their distribution. A close, positive correlation was found between ciliate and flagellate abundance, together with a frequent overlap of their patches. These findings suggest that they interact or respond to the same environmental factors. The scarcity of bacterivorous ciliate species in the area could account for the lack of correlation between ciliates and aerobic-heterotrophic bacteria. Differences in the spatial distribution of interstitial oxygen content and porosity, over small distances, were also found. Some species seem to be sensitive to these factors, but an influence on overall ciliate abundance was not identified. Variations were found in ciliate taxonomic composition between neighbouring samples; they may be explained by local, undetermined, microenvironmental factors or by different recolonization phases in each sample.
\end{abstract}

KEY WORDS: Sandy shore - Distribution pattern - Interstitial environment - Ciliates - Mediterranean Sea

\section{INTRODUCTION}

Marine-bottom sediments should be considered a heterogeneous environment (Fenchel 1987a, 1990, Graf 1989, Bin et al. 1993) but very little is known about the actual small-scale distribution of marine interstitial microorganisms, since the spatial structure of sandy beaches is generally described on a large scale (Brown \& McLachlan 1990). The role of foraminifera patchiness in interstitial communities was analyzed by Chandler (1989) and the spatial structure of microphytobenthos assemblages at different scales was described by Saburova \& Polikarpov (1993). A characterization of vertical distribution of ciliates in the Baltic Sea coastal beaches was carried out by Fenchel (1967, 1969), who found that ciliates are substantially more numerous than metazoans and exceed meiofauna in biomass in medium to fine sand. No data is available on the spatial distribution pattern of interstitial ciliate communities from Mediterranean sandy bottoms. In this paper we have analysed the commu- nity composition of marine interstitial ciliates from an exposed Mediterranean beach and their spatial distribution.

Variations in environmental factors over space affect the distribution pattern of ciliates profoundly (Fenchel 1987b). We tried, therefore, to identify environmental heterogeneity factors that, changing over small distances, may influence ciliate microdistribution patterns. Out of the great numbers of microscopic organisms that live in interstices, and the numerous abiotic parameters that may affect interstitial environments, we focused on some microorganisms generally considered to be food sources for ciliates, and on those abiotic variables (oxygen and space) which are deemed the main limiting factors in the interstitial environment (Brown \& McLachlan 1990). Some species of ciliates are known to be extremely sensitive to dissolved oxygen (Finlay et al. 1986, Fenchel et al. 1989, Fenchel \& Finlay 1991). Availability of space may greatly affect the distribution of interstitial ciliates; porosity was chosen as a descriptor for this space (Giere et al. 1988). 
The present research work was carried out in an exposed, medium-grained sandy beach of the Mediterranean. The sandy shore is perturbed deeply and frequently by storms that homogenize the environment. Previous studies (Santangelo \& Lucchesi 1992, Lucchesi \& Santangelo 1993) indicate that ciliates show a higher overall abundance and a more heterogeneous distribution during the spring-summer period, at which time the uppermost layer harbours the lowest number of ciliates. During autumn-winter density was found to be lower, ciliate distribution pattern was more even and no significant difference in ciliate density was found between different sandy layers (Lucchesi \& Santangelo 1992, 1993). These results suggested that ciliates tend to form patches during spring-summer and that environmental heterogeneity may control their distribution patterns.

\section{MATERIALS AND METHODS}

Sampling was performed in shallow waters of the Italian Ligurian Sea, during the spring-summer period. One sampling site (Station A) was located about $10 \mathrm{~m}$ from the shore, near Viareggio (435 $\left.51^{\prime} \mathrm{N}, 10^{\circ} 15^{\prime} 05^{\prime \prime} \mathrm{E}\right)$. A second sampling site (Stations $B$ and $C$ ) was located about $5 \mathrm{~m}$ from the shore, at $\mathrm{S}$. Rossore Natural Park,

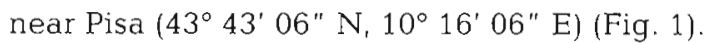

Sampling was always carried out in the morning, during low tide, at about $50 \mathrm{~cm}$ water depth, by pressing 2 adjacently placed $2 \mathrm{~cm}$ diameter glass tubes $9 \mathrm{~cm}$ into the sandy bottom. The glass tubes were then closed at each end with a cork. Two adjacent sandy cores were collected, one for the analysis of microbial population and one for porosity (Giere et al. 1988). These pairs of adjacent cores were collected at $10 \mathrm{~cm}$ intervals at the knots of a square grid. Distances between knots were determined by a plexiglass framework. Grids were composed of 4 or 9 pairs of cores as shown in Fig. 2a. Each core was divided into 3 different fractions, $9.42 \mathrm{~cm}^{3}$ each, corresponding to different depths in the sandy bottom $(0-3,3-6,6-9 \mathrm{~cm})$. The working procedure followed to examine 2 adjacent cores is reported in Fig. 2b. In some cases, microbial populations could only be analysed in 5 neighbouring cores out of a 9 core grid due to the need to analyse samples within $6 \mathrm{~h}$. Thus, 123 pairs of cores (for a total of 369 pairs of fractions) were collected during springsummer in 26 samplings

Each core fraction was collected in a sterile vial, carried to the lab in a thermal bag and examined within $6 \mathrm{~h}$. Core fractions, homogenised by gentle shaking, were divided in 2 equal parts. One part was then analysed for ciliate, flagellate and diatom content while the other was analysed for aerobic-heterotrophic bacteria (A.H. bacteria). Two replicates, $1 \mathrm{~cm}^{3}$ each, were taken from the first part and filtered with a $250 \mu \mathrm{m}$ mesh nylon net. Extraction was made following Uhlig's ice-water method (Uhlig 1964). Uhlig (1964) and Fenchel (1967) have attributed a 90\% efficiency rate to this method of ciliate and flagellate extraction. The 2 replicates of $1 \mathrm{~cm}^{3}$ each were found to contain $99 \%$ of the species present in the core fraction $\left(9.42 \mathrm{~cm}^{3}\right)$. The numerical difference between the 2 replicates was not significant, as determined by a chisquare test applied to the comparison between 2 counts (Armitage 1971).

Quantitative and qualitative analyses of ciliates, flagellates, and diatoms were carried out under both dissection and standard light microscope. In most cases quantitative data refer to genera more than species due to the difficulty in collecting both qualitative and quantitative data on ciliates simultaneously. Identification of ciliates, on living and stained cells, was carried out following Corliss' classification (Corliss 1979). Species descriptions by Kahl $(1930,1935)$, Dragesco (1960,

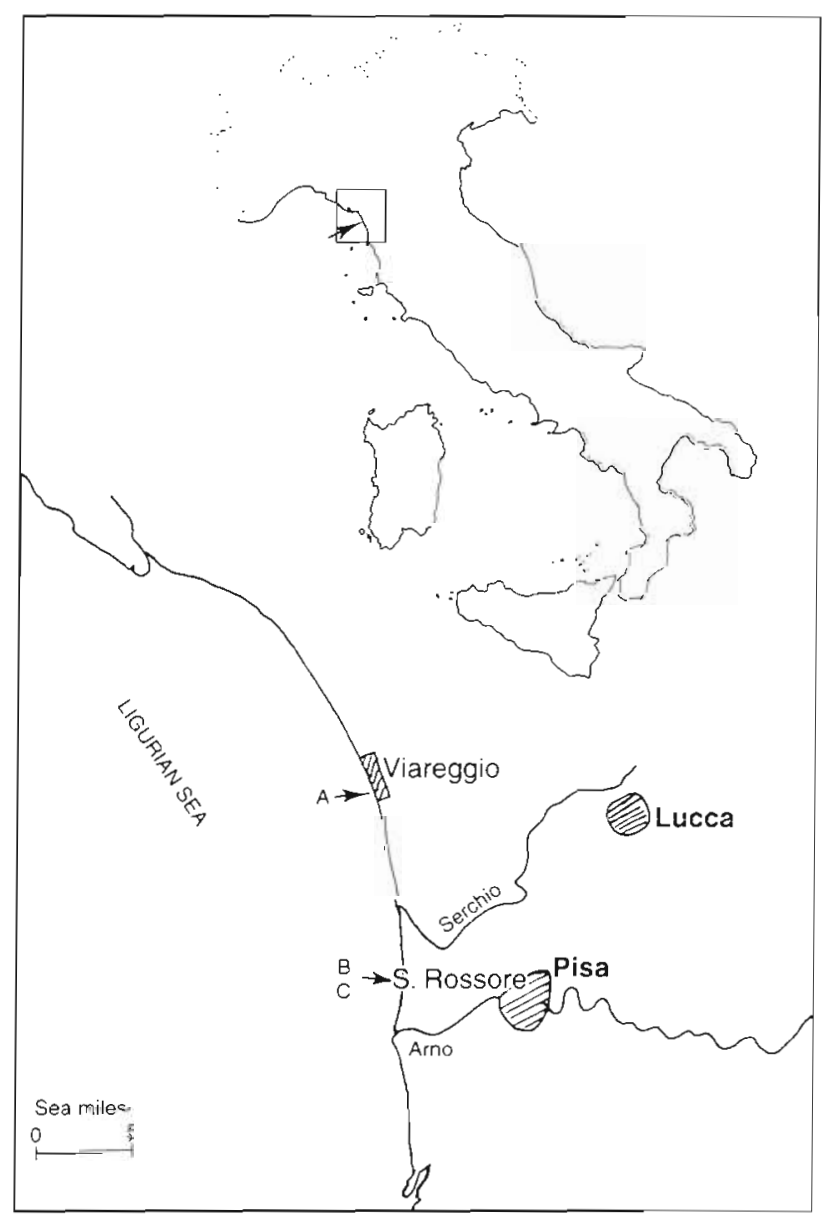

Fig. 1 Map of the Ligurian Sea coast north of the Arno river mouth. Arrows indicate the areas studied 

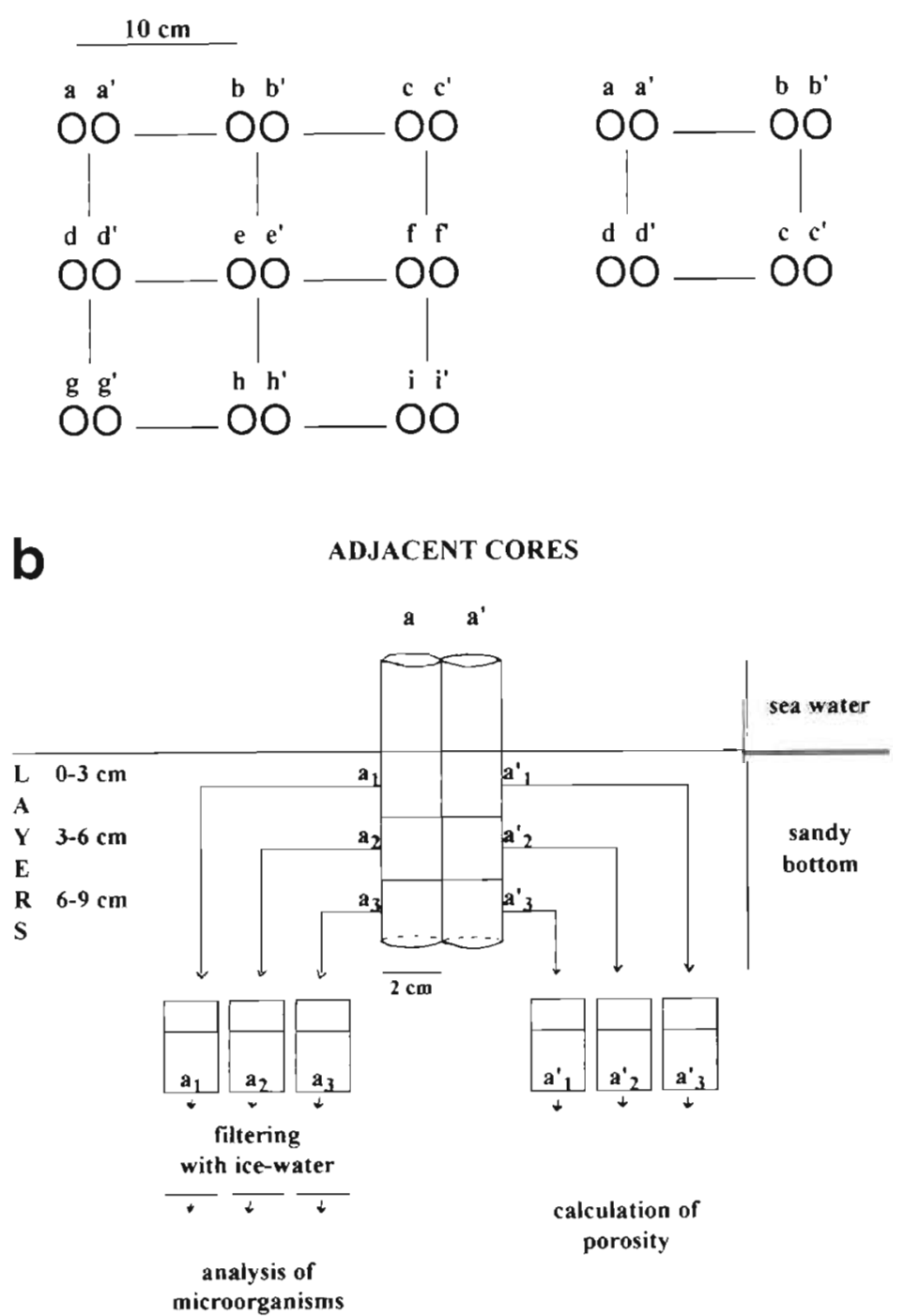

Fig. 2. (a) Example of the working procedure followed to sample pairs of adjacent sandy cores arranged in square grids of 9 and 4 pairs each. (b) Working procedure followed to examine 2 adjacent cores

1965), Dragesco \& Dragesco-Kerneis (1986), Ricci et al. (1982), Wright (1983), and Carey (1992) were also utilized. Cells were stained by green methyl, phosphateacetic-carmine and Chatton-Lwoff silver method (Lee et al. 1985). Some culturable hypotrichs were also examined by SEM (Verni \& Rosati 1990).

Abundance of A.H. bacteria was estimated, in the other half of the sand fraction, on the basis of the number of colony-forming units growing on marinenutrient agar (DIFCO plate count agar) (Legendre \& Troussellier 1988). Sand samples were washed with axenic marine water $6 \mathrm{~h}$ after collection and the supernatant was spread-plated at a series of dilutions and incubated at $24^{\circ} \mathrm{C}$ for $72 \mathrm{~h}$. Mechanical shaking was utilized to wash off bacteria from sand grains. This entire procedure was carried out by the same investigator (P.L.). It must be mentioned that the bacterial population is only partly revealed in this way, and so many groups (e.g non culturable, anaerobic and autotrophic bacteria) are excluded from this analysis

In order to prevent any disturbance to the microbial population samples, interstitial oxygen content was measured by an oxygen meter (Hanna Instruments) adjacently to each such core (as explained in Santangelo \& Lucchesi 1992).

Porosity was derived from the difference between the weight of wet and oven-dried sand samples converted into porosity by a standardized procedure (Buchanan 1984). Sand was dried at $99^{\circ} \mathrm{C}$ overnight.

Parametric statistical analyses were performed on natural logarithms of count data.

\section{RESULTS}

Abundance of cilates varied, within the overall sampling, between 0 and 401 cells $\mathrm{cm}^{-3}$. The distribution of ciliates in contemporary samples collected at $10 \mathrm{~cm}$ intervals along a square-grid array was tested on the basis of chi-square variance to mean ratio (Elliott 1977). This analysis revealed a patched distribution $(p<0.05)$ in $56 \%$ of cases (Table 1).

Patches of ciliates were present in each sandy layer, and a chi-square test applied to their frequency (Table 1) shows that no significant difference in patchiness frequency was detectable between different layers. Some species show a preference for a particular layer: species of the microarophylic genus Remanella were found, in 13 cases out of 20 , within the deepest one. Patches are limited, in the majority of cases $(63 \%)$, to one fraction only of a core (chi-square test, $\mathrm{p}<0.05$ ) and many species belonging to different genera contribute to form a single patch. An example of a patched distribution pattern is given in Table 2, in which the species assemblage in 4 neighbouring cores is reported. An example of the alternative pattern, in which ciliates showed a random distribution, a low overall density and no dominance, is reported in Table 3.

The 'resident population' was composed of 8 'resident genera', defined as those present in more than $20 \%$ of samples (these are listed in Table 4). 
Table 1. Average abundance of ciliates, flagellates and aerobic, heterotrophic bacteria for each sampling by layer. "Significant differences between cores for the layer, $\mathrm{p}<0.05$. A.H. bacterial abundance must be considered as $10^{n}(x \pm S D)$

\begin{tabular}{|c|c|c|c|c|c|c|c|c|c|c|c|c|c|c|c|c|}
\hline \multirow[t]{2}{*}{ Sampling } & \multirow{2}{*}{$\begin{array}{l}\text { No of } \\
\text { cores }\end{array}$} & \multicolumn{4}{|c|}{ Ciliates (cells $\mathrm{cm}^{-3}$ ) } & \multicolumn{4}{|c|}{ Flagellates (cells $\mathrm{cm}^{-3}$ ) } & \multicolumn{7}{|c|}{ A.H. bacteria (cells $\mathrm{cm}^{-3}$ ) } \\
\hline & & $0-3 \mathrm{~cm}$ & $3-6 \mathrm{~cm}$ & & $6-9 \mathrm{~cm}$ & $0-3 \mathrm{~cm}$ & & $3-6 \mathrm{~cm}$ & $6-9 \mathrm{~cm}$ & & $0-3 \mathrm{~cm}$ & $n$ & $3-6 \mathrm{~cm}$ & $n$ & $6-9 \mathrm{~cm}$ & $n$ \\
\hline \multicolumn{17}{|l|}{ Station A } \\
\hline 19 Sep 1989 & 9 & $2 \pm 2$ & $2 \pm 5$ & & $6 \pm 3$ & $5 \pm 7$ & - & $2 \pm 2$ & $2 \pm 2$ & & & & & & & \\
\hline 13 Nov 1989 & 9 & $1 \pm 1$ & $1 \pm 2$ & & $2 \pm 2$ & $2 \pm 4$ & . & $2 \pm 2$ & $2 \pm 2$ & & & & & & & \\
\hline $12 \operatorname{Mar} 1990$ & 9 & $19 \pm 11$ & - $20 \pm 10$ & - & $19 \pm 11$ & $12 \pm 7$ & • & $10 \pm 6$ & $9 \pm 5$ & - & & & & & & \\
\hline 19 Mar 1990 & 5 & $84 \pm 102$ & - $256 \pm 133$ & - & $79 \pm 115$ & $43 \pm 42$ & • & $525 \pm 548$ & $30 \pm 23$ & - & & & & & & \\
\hline 18 Jun 1990 & 4 & $6 \pm 2$ & $25 \pm 34$ & - & $27 \pm 5$ & $22 \pm 6$ & & $20 \pm 15$ & $17 \pm 8$ & - & $5 \pm 5$ & 4 & $36 \pm 26$ & 3 & $38 \pm 39$ & 3 \\
\hline 28 Jun 1990 & 4 & $16 \pm 8$ & $138 \pm 187$ & - & $91 \pm 33$ & $7 \pm 3$ & & $16 \pm 11$ & $27 \pm 8$ & & $17 \pm 32$ & 4 & $3 \pm 0.1$ & 6 & $5 \pm 8$ & 2 \\
\hline 17 Jul 1990 & 4 & $103 \pm 184$ & - $187 \pm 88$ & - & $63 \pm 44$ & $2 \pm 3$ & & $64 \pm 41$ & $52 \pm 51$ & - & $6 \pm 4$ & 6 & $8 \pm 6$ & 6 & $1 \pm 1$ & 7 \\
\hline 23 Jul 1990 & 5 & $49 \pm 92$ & - $148 \pm 159$ & - & $12 \pm 11$ & . $2 \pm 2$ & & $10 \pm 9$ & $1 \pm 1$ & & $3 \pm 4$ & 6 & $1 \pm 1$ & 6 & $29 \pm 47$ & 4 \\
\hline 11 Sep 1990 & 5 & $35 \pm 32$ & · $\quad 33 \pm 28$ & - & $10 \pm 11$ & - $178 \pm 212$ & · & $93 \pm 179$ & $7 \pm 8$ & * & $9 \pm 4$ & 3 & $9 \pm 4$ & 3 & $6 \pm 3$ & 3 \\
\hline \multicolumn{17}{|l|}{ Station B } \\
\hline 21 May 1991 & 4 & $4 \pm 4$ & $7 \pm 6$ & - & $3 \pm 3$ & $12 \pm 21$ & - & $4 \pm 1$ & $3 \pm 5$ & . & $1 \pm 1$ & 3 & $1 \pm 1$ & 3 & $13 \pm 9$ & 3 \\
\hline 28 May 1991 & 4 & $5 \pm 4$ & $9 \pm 5$ & & $3 \pm 2$ & $2 \pm 2$ & & $6 \pm 4$ & $1 \pm 2$ & & $14 \pm 8$ & 2 & $2 \pm 2$ & 3 & & \\
\hline $11 \mathrm{Jul} 1991$ & 4 & $30 \pm 41$ & $16 \pm 16$ & - & $12 \pm 15$ & $3 \pm 3$ & & $11 \pm 9$ & $4 \pm 1$ & & $1 \pm 1$ & 3 & $3 \pm 3$ & 3 & $1 \pm 1$ & 3 \\
\hline 17 Jul 1991 & 4 & $1 \pm 1$ & $1 \pm 1$ & & $1 \pm 1$ & $4 \pm 4$ & & $1 \pm 1$ & $2 \pm 2$ & & $7 \pm 3$ & 3 & $1 \pm 2$ & 3 & $3 \pm 2$ & 3 \\
\hline 8 May 1992 & 4 & $1 \pm 1$ & $5 \pm 3$ & & $7 \pm 3$ & $1 \pm 1$ & & $6 \pm 3$ & $8 \pm 3$ & & & & & & & \\
\hline 14 May 1992 & 4 & $23 \pm 20$ & $29 \pm 16$ & - & $10 \pm 8$ & $55 \pm 96$ & & $53 \pm 52$ & $10 \pm 18$ & - & & & & & & \\
\hline 20 May 1992 & 4 & $7 \pm 10$ & $10 \pm 9$ & . & $16 \pm 6$ & $7 \pm 5$ & & $7 \pm 6$ & $7 \pm 7$ & . & & & & & & \\
\hline 26 May 1992 & 4 & $5 \pm 2$ & $10 \pm 4$ & & $7 \pm 5$ & $6 \pm 3$ & & $11 \pm 7$ & $3 \pm 3$ & & & & & & & \\
\hline \multicolumn{17}{|l|}{ Station C } \\
\hline 21 May 1991 & 4 & $2 \pm 1$ & $1 \pm 1$ & & $6 \pm 9$ & $1 \pm 1$ & & $1 \pm 1$ & $3 \pm 4$ & & & & & & & \\
\hline 28 May 1991 & 4 & $8 \pm 4$ & $10 \pm 10$ & ' & $14 \pm 11$ & $10 \pm 11$ & - & $10 \pm 12$ & $4 \pm 2$ & & $1 \pm 1$ & 4 & $6 \pm 3$ & 3 & $4 \pm 5$ & 3 \\
\hline 11 Jul 1991 & 4 & $16 \pm 15$ & $25 \pm 23$ & . & $43 \pm 36$ & $6 \pm 5$ & & $8 \pm 7$ & $30 \pm 25$ & - & $3 \pm 3$ & 3 & $3 \pm 2$ & 3 & $4 \pm 4$ & 3 \\
\hline 17 Jul 1991 & 4 & $34 \pm 44$ & $86 \pm 72$ & - & $66 \pm 31$ & $19 \pm 14$ & - & $33 \pm 35$ & $26 \pm 21$ & - & $6 \pm 2$ & 2 & $2 \pm 4$ & 3 & $8 \pm 14$ & 3 \\
\hline 8 May 1992 & 4 & $4 \pm 6$ & $9 \pm 6$ & $\cdot$ & $5 \pm 4$ & $13 \pm 15$ & - & $10 \pm 7$ & $12 \pm 5$ & & & & & & & \\
\hline 14 May 1992 & 4 & $13 \pm 5$ & $9 \pm 9$ & . & $8 \pm 8$ & $17 \pm 6$ & & $12 \pm 25$ & $2 \pm 3$ & & & & & & & \\
\hline 20 May 1992 & 4 & $9 \pm 4$ & $7 \pm 2$ & & $5 \pm 1$ & $14 \pm 7$ & & $13 \pm 11$ & $7 \pm 4$ & & & & & & & \\
\hline 26 May 1992 & 4 & $3 \pm 3$ & $10 \pm 5$ & & $24 \pm 29$ & $31 \pm 24$ & - & $7 \pm 2$ & $35 \pm 46$ & - & & & & & & \\
\hline
\end{tabular}

Diatoms were scarce in these samples $(0$ to 10 cells $\mathrm{cm}^{-3}$ ) and were found only in the uppermost sandy layer, through which they were irregularly spread.

Flagellates showed a fluctuating abundance 10 to 1000 cells $\left.\mathrm{cm}^{-3}\right)$, and a patched distribution $(\mathrm{p}<0.05)$ in $48 \%$ of cases, as shown by chi-square variance to mean ratio (Elliott 1977) (Table 1). The vertical distribution pattern of flagellates is extremely heterogeneous but, in contrast to that of ciliates, no significant difference in distribution between different sandy layers was found (ANOVA).

A.H. bacteria ranged from 10 to $10^{7}$ cells $\mathrm{cm}^{-3}$ and their horizontal distribution, at the spatial scale examined, proved to be heterogeneous, as the means and standard deviations reported in Table 1 show. Differences in the vertical distribution of A.H. bacteria abundance were found to be not significant (ANOVA).

The analysis of the distribution of ciliates and flagellates shows a highly significant, positive correlation between the 2 densities $(r=0.73, p<0.001)$. An example of the overlap in their densities is reported in the last 2 rows of Table 2. No significant correlation was found between ciliates and A.H. bacteria. In contrast A.H. bacteria were negatively correlated with flagellates $(r=-0.473, p=0.0244)$.

Interstitial oxygen was, on the average, half that measured in water column. The average values and standard deviations of this factor indicate some variation between neighbouring cores, as reported in Table 5. No correlation was found between oxygen and overall abundance of ciliates, but some species, such as those of the genus Remanella, seemed to be sensitive to this factor (Fenchel 1987a, Lucchesi \& Santangelo 1993).

Average porosity values and standard deviations indicate some variation between neighbouring samples. This parameter varies significantly in different sandy layers at Station A only (ANOVA, p < 0.006); these differences are mainly due to the values found in the deepest layer which shows lowest averages and standard deviations (Table 5). This finding may be due to the higher hydrodynamism in this station, which is more exposed than the other two.

No correlation between porosity and overall ciliate and flagellate abundance was found. Nevertheless, 
Table 2. An example of patchy distribution of ciliates: ciliate abundance in each sandy core and in each core fraction (out of a 4 core grid) are reported. In the last 2 rows, the overall number of ciliates and flagellates found in each core fraction is reported

\begin{tabular}{|c|c|c|c|c|c|c|c|c|c|c|c|c|}
\hline \multirow{2}{*}{$\begin{array}{l}\text { Layer: } \\
\text { Core: }\end{array}$} & \multicolumn{4}{|c|}{$0-3 \mathrm{~cm}$} & \multicolumn{4}{|c|}{$3-6 \mathrm{~cm}$} & \multicolumn{4}{|c|}{$6-9 \mathrm{~cm}$} \\
\hline & $a_{1}$ & $b_{1}$ & $c_{1}$ & $d_{1}$ & $a_{2}$ & $\mathrm{~b}_{2}$ & $\mathrm{C}_{2}$ & $\mathrm{~d}_{2}$ & $a_{3}$ & $b_{3}$ & $c_{3}$ & $d_{3}$ \\
\hline Trachelocerca sp. & & & & & 3 & & & & & & & 1 \\
\hline Trachelonema spp. & 1 & 5 & 2 & 1 & & & & 1 & & 3 & & 1 \\
\hline Tracheloraphis sp. & 1 & 4 & 2 & & 2 & & & & & 2 & & 1 \\
\hline Kentrophorous sp. & & & & & & & & & & & & 1 \\
\hline \multicolumn{13}{|l|}{ Remanella ( $R$. caudata, } \\
\hline $\begin{array}{l}\text { R. margaritifera, } R \text {. obtusa, } \\
\text { R. rugosa, R. swedmarki) }\end{array}$ & 2 & 12 & & & 11 & 5 & & 1 & 2 & & 2 & 4 \\
\hline Geleia sp. & & 8 & 2 & & & & & & & 2 & & \\
\hline \multicolumn{13}{|l|}{ Coleps (C. hirtus, } \\
\hline C. pulcher) & & & & & & & & 1 & & 6 & & \\
\hline \multicolumn{13}{|l|}{ Lacrymaria (L. coronata, } \\
\hline L. marina) & & & & & 2 & & 13 & & & & & 1 \\
\hline \multicolumn{13}{|l|}{ Frontonia ( $F$. arenaria, } \\
\hline F. microstomata) & 7 & 46 & 1 & 1 & 65 & 91 & 20 & 10 & 55 & 4 & 67 & 2 \\
\hline \multicolumn{13}{|l|}{ Pleuronema $(P$ coronatum, } \\
\hline P. marinum) & & 12 & & 7 & 34 & 17 & & 3 & 31 & 63 & 4 & 7 \\
\hline Cyclidium spp. & & & & 3 & 14 & 6 & & & & & & \\
\hline Holosticha sp. & & & & & 8 & & & & & & & \\
\hline Psammomitra spp. & 2 & 15 & 2 & & & & & 1 & & & 3 & \\
\hline Trachelostyla sp. & & & & & 6 & 2 & & & & & & \\
\hline Gastrostyla sp. & & & & & 18 & 3 & & & & & & \\
\hline Diophrys scutum & & & & & 1 & & & & & & & \\
\hline Others & & & 1 & & 5 & & & & & & & 1 \\
\hline Ciliates & 13 & 102 & 10 & 12 & 169 & 124 & 33 & 17 & 88 & 80 & 76 & 19 \\
\hline Flagellates & 24 & 36 & 6 & 10 & 40 & 79 & 6 & 6 & 18 & 58 & 21 & 10 \\
\hline
\end{tabular}

some taxa show a tendency to dwell within a welldefined porosity range: Lacrymaria between 28 and $48 \%$ and Frontonia between 28 and $41 \%$ atm sat. A significant, inverse relationship was found between porosity and A.H. bacterial abundance $(r=-0.31, p=$ $0.03)$. Bacteria in the sand are mostly attached to sand grains and their density is, therefore, linked to the total surface area of grains; this last parameter is inversely correlated with porosity (Brown \& McLachlan 1990).

\section{DISCUSSION AND CONCLUSIONS}

The aim of this research was to analyze the microdistribution patterns of ciliates dwelling in marine sand

Table 3. An example of random distribution of ciliates. Abundances in each core and in each core fraction are reported, together with the overall number of ciliates and flagellates (last 2 rows)

\begin{tabular}{|c|c|c|c|c|c|c|c|c|c|c|c|c|}
\hline Layer: & \multicolumn{4}{|c|}{$0-3 \mathrm{~cm}$} & \multicolumn{4}{|c|}{$3-6 \mathrm{~cm}$} & \multicolumn{4}{|c|}{$6-9 \mathrm{~cm}$} \\
\hline Core: & $\mathrm{a}_{1}$ & $\mathbf{b}_{1}$ & $\mathrm{c}_{1}$ & $d_{1}$ & $\mathrm{a}_{2}$ & $b_{2}$ & $\mathrm{C}_{2}$ & $d_{2}$ & $a_{3}$ & $\mathrm{~b}_{3}$ & $\mathrm{C}_{3}$ & $d_{3}$ \\
\hline Remanella margaritifera & & & & & & & & & 1 & & & \\
\hline Coleps hirtus & & & & & & & & & & 1 & 1 & \\
\hline Trachelius sp. & & 6 & & & & & & & & & & \\
\hline Pleuronema marinum & 3 & 3 & 4 & & 2 & 1 & 12 & 11 & 1 & 1 & 3 & \\
\hline Strombidium sp. & & 2 & & & & & & & & & & \\
\hline Diophrys scutum & & & & & & & & & & & 2 & \\
\hline Euplotes crassus & & & & & & & & & & 1 & & \\
\hline Uronychia setigera & & & & & & & & & & 1 & & \\
\hline Others & & & & & & & & & & & 1 & \\
\hline Ciliates & 3 & 11 & 4 & 0 & 2 & 1 & 12 & 11 & 2 & 4 & 7 & 0 \\
\hline Flagellates & 1 & 44 & 1 & 2 & 2 & 10 & 3 & 1 & 1 & 1 & 10 & 0 \\
\hline
\end{tabular}


Table 4. Abundance of each resident genus in each core from Stations A and C

\begin{tabular}{|c|c|c|c|c|c|c|c|c|}
\hline Date & Trachelocerca & Trachelonema & Tracheloraphis & Remanella & Coleps & Lacrymaria & Pleuronema & Frontonia \\
\hline \multicolumn{9}{|c|}{ Station A (Viareggio) } \\
\hline 18 Jun 1990 & 0 & 3 & 5 & 5 & 75 & 0 & 14 & 0 \\
\hline $18 \mathrm{Jun} 1990$ & 1 & 1 & 5 & 9 & 13 & 0 & 5 & 0 \\
\hline 18 Jun 1990 & 1 & 2 & 4 & 0 & 15 & 0 & 14 & 0 \\
\hline 18 Jun 1990 & 5 & 2 & 9 & 9 & 6 & 0 & 8 & 0 \\
\hline 28 Jun 1990 & 2 & 2 & 6 & 1 & 72 & 5 & 462 & 0 \\
\hline 28 Jun 1990 & 1 & 0 & 2 & 1 & 38 & 6 & 87 & 1 \\
\hline 28 Jun 1990 & 1 & 0 & 0 & 1 & 61 & 0 & 48 & 0 \\
\hline 28 Jun 1990 & 2 & 0 & 1 & 1 & 30 & 1 & 83 & 4 \\
\hline 17 Jul 1990 & 1 & 0 & 1 & 0 & 7 & 0 & 263 & 4 \\
\hline 17 Jul 1990 & 4 & 0 & 0 & 4 & 14 & 0 & 297 & 5 \\
\hline 17 Jul 1990 & 2 & 0 & 1 & 1 & 25 & 0 & 664 & 0 \\
\hline 17 Jul 1990 & 0 & 0 & 1 & 6 & 18 & 0 & 85 & 0 \\
\hline 23 Jul 1990 & 2 & 1 & 2 & 1 & 3 & 2 & 215 & 0 \\
\hline 23 Jul 1990 & 0 & 0 & 1 & 0 & 0 & 2 & 13 & 0 \\
\hline 23 Jul 1990 & 0 & 0 & 0 & 0 & 3 & 2 & 83 & 0 \\
\hline $23 \mathrm{Jul} 1990$ & 1 & 0 & 2 & 0 & 0 & 4 & 430 & 0 \\
\hline 1.1 Sep 1990 & 1 & 4 & 3 & 0 & 2 & 2 & 154 & 3 \\
\hline 11 Sep 1990 & 0 & 1 & 1 & 0 & 0 & 1 & 97 & 1 \\
\hline 11 Sep 1990 & 0 & 1 & 1 & 0 & 0 & 2 & 32 & 0 \\
\hline 11 Sep 1990 & 1 & 0 & 1 & 0 & 1 & 2 & 30 & 0 \\
\hline \multicolumn{9}{|c|}{ Station C (San Rossore) } \\
\hline 21 May 1991 & 0 & 1 & 1 & 0 & 1 & 0 & 4 & 0 \\
\hline 21 May 1991 & 0 & 0 & 0 & 0 & 0 & 0 & 1 & 0 \\
\hline 21 May 1991 & 0 & 0 & 2 & 0 & 1 & 0 & 2 & 0 \\
\hline 21 May 1991 & 0 & 0 & 0 & 0 & 1 & 0 & 20 & 0 \\
\hline 28 May 1991 & 1 & 1 & 3 & 23 & 7 & 2 & 19 & 0 \\
\hline 28 May 1991 & 0 & 0 & 5 & 5 & 3 & 0 & 11 & 0 \\
\hline 28 May 1991 & 3 & 0 & 2 & 0 & 3 & 0 & 10 & 0 \\
\hline 28 May 1991 & 4 & 1 & 5 & 4 & 1 & 1 & 11 & 0 \\
\hline $11 \mathrm{Jul} 1991$ & 19 & 3 & 24 & 2 & 0 & 2 & 21 & 17 \\
\hline 11 Jul 1991 & 4 & 1 & 5 & 3 & 0 & 2 & 13 & 6 \\
\hline 11 Jul 1991 & 1 & 10 & 11 & 0 & 3 & 3 & 7 & 5 \\
\hline $11 \mathrm{Jul} 1991$ & 5 & 10 & 7 & 1 & 0 & 3 & 21 & 2 \\
\hline 17 Jul 1991 & 3 & 1 & 3 & 15 & 0 & 2 & 65 & 127 \\
\hline 17 Jul 1991 & 0 & 8 & 6 & 17 & 6 & 0 & 92 & 141 \\
\hline 17 Jul 1991 & 0 & 2 & 2 & 2 & 0 & 13 & 4 & 88 \\
\hline 17 Jul 1991 & 1 & 3 & 1 & 5 & 1 & 1 & 17 & 13 \\
\hline
\end{tabular}

together with selected environmental features. Ciliates tend to stratify a few centimeters below the sand surface and to form patches; both these tendencies characterise the spring-summer period, in which overall ciliate abundance reaches its yearly peak (Santangelo \& Lucchesi 1992, Lucchesi \& Santangelo 1993).

On the basis of the data here reported an estimation of ciliate patch size (at the scale examined) can be made: patches, although present at each layer, do not, in the majority of cases, exceed the height of one layer $(3 \mathrm{~cm})$. In the same way, the finding that density significantly changes between samples collected at a distances of only $10 \mathrm{~cm}$ suggests that patches do not horizontally exceed this measure. These patches are small, measuring no more than several hundred or a few thousand times the average length of a ciliate. While it is easy to understand why single species show a patched pattern, it is less obvious why whole ciliate assemblages should show this type of distribution. This result suggests that ciliates of different species respond to the same microenviromental factors. The clear-cut, patched distribution found may be due to the heterogeneous nature of the interstitial environment. Environmental heterogeneity may arise from many causes among which we focused on the distribution of 2 groups of microorganisms and 2 abiotic factors.

As reported above, flagellate and A.H. bacteria densities, interstitial dissolved oxygen and porosity values vary over small distances; their distributions therefore generate heterogeneity. The abundances of flagellates and ciliates follow similar trends, and their patches often overlap. The strong, positive correlation between flagellate and ciliate distribution suggests 2 hypotheses: (1) the 2 groups of organisms respond to the same 
Table 5. Porosity and oxygen values ( $x \pm \mathrm{SD})$ measured in each sampling for each layer

\begin{tabular}{|c|c|c|c|c|c|}
\hline \multirow[t]{2}{*}{ Sampling } & \multirow{2}{*}{$\begin{array}{l}\text { No. of } \\
\text { cores }\end{array}$} & \multicolumn{3}{|c|}{ Porosity $(\%)$} & \multirow{2}{*}{$\begin{array}{l}\text { Oxygen } \\
\left(m g l^{-1}\right)\end{array}$} \\
\hline & & $0-3 \mathrm{~cm}$ & $3-6 \mathrm{~cm}$ & $6-9 \mathrm{~cm}$ & \\
\hline \multicolumn{6}{|l|}{ Station A } \\
\hline 19 Sep 1989 & 9 & & & & \\
\hline 13 Nov 1989 & 9 & & & & $3.7 \pm 0.2$ \\
\hline $12 \operatorname{Mar} 1990$ & 9 & & & & \\
\hline 19 Маг 1990 & 5 & & & & \\
\hline 18 Jun 1990 & 4 & $41 \pm 10$ & $29 \pm 4$ & $26 \pm 7$ & $2.1 \pm 0.2$ \\
\hline 28 Jun 1990 & 4 & $14 \pm 8$ & & & $3.5 \pm 0.9$ \\
\hline 17 Jul 1990 & 4 & $30 \pm 14$ & $39 \pm 0$ & $27 \pm 7$ & \\
\hline 23 Jul 1990 & 5 & $34 \pm 11$ & $29 \pm 4$ & $28 \pm 6$ & $1.9 \pm 0.8$ \\
\hline 11 Sep 1990 & 5 & $32 \pm 7$ & $26 \pm 4$ & $23 \pm 3$ & $2.7 \pm 0.7$ \\
\hline \multicolumn{6}{|l|}{ Station B } \\
\hline 21 May 1991 & 4 & $30 \pm 4$ & $26 \pm 1$ & $28 \pm 4$ & $3.3 \pm 0.4$ \\
\hline 28 May 1991 & 4 & $29 \pm 4$ & $28 \pm 4$ & $30 \pm 2$ & $2.7 \pm 0.9$ \\
\hline 11 Jul 1991 & 4 & $20 \pm 9$ & $26 \pm 5$ & $24 \pm 6$ & $2 \pm 0.9$ \\
\hline 17 Jul 1991 & 4 & $19 \pm 11$ & $24 \pm 3$ & $26 \pm 3$ & $3.8 \pm 0.5$ \\
\hline 8 May 1992 & 4 & $34 \pm 10$ & $30 \pm 2$ & $39 \pm 9$ & \\
\hline 14 May 1992 & 4 & $17 \pm 4$ & $18 \pm 1$ & $17 \pm 1$ & $3.3 \pm 1.5$ \\
\hline 20 May 1992 & 4 & $33 \pm 8$ & $28 \pm 2$ & $32 \pm 7$ & $4.4 \pm 0.9$ \\
\hline 26 May 1992 & 4 & $25 \pm 2$ & $24 \pm 2$ & $25 \pm 2$ & $3.6 \pm 2.1$ \\
\hline \multicolumn{6}{|l|}{ Station C } \\
\hline 21 May 1991 & 4 & $27 \pm 8$ & $26 \pm 1$ & $27 \pm 9$ & $3.3 \pm 0.7$ \\
\hline 28 May 1991 & 4 & $34 \pm 7$ & $25 \pm 1$ & $33 \pm 7$ & $2.5 \pm 0.8$ \\
\hline 11. Jul 1991 & 4 & $20 \pm 8$ & $27 \pm 17$ & $15 \pm 7$ & $2.1 \pm 1.1$ \\
\hline 17 Jul 1991 & 4 & $29 \pm 2$ & $23 \pm 8$ & $26 \pm 2$ & $1.7 \pm 0.6$ \\
\hline 8 May 1992 & 4 & $25 \pm 12$ & $33 \pm 12$ & $30 \pm 1$ & \\
\hline 14 May 1992 & 4 & $17 \pm 5$ & $17 \pm 5$ & $18 \pm 1$ & $3.7 \pm 1$ \\
\hline 20 May 1992 & 4 & $29 \pm 3$ & $28 \pm 8$ & $31 \pm 7$ & $4.8 \pm 0.2$ \\
\hline 26 May 1992 & 4 & $24 \pm 2$ & $25 \pm 1$ & $24 \pm 3$ & $1.4 \pm 0.3$ \\
\hline
\end{tabular}

environmental factor(s); (2) ciliates feed on flagellate patches, but they cannot significantly reduce flagellate density due to the higher growth rate of these latter microorganisms.

A.H. bacteria are generally considered to comprise only a small part of interstitial bacteria; nevertheless they may have greater importance in an exposed, oxygenated beach, like that examined here. These bacteria show a negative relationship with flagellates and with porosity but no correlation with the abundance of ciliates. In this community, ciliate species that may be considered bacterivorous (following Fenchel 1968) were not numerous and flagellates, rather than ciliates might control the abundance of this component of the bacterial assemblage. Fenchel (1969) found that in interstitial microcommunities of the Baltic Sea, bacteria play a minor role as food sources for ciliates. More recently, Kemp (1988) suggested that ciliates are less important than flagellates as vectors for direct transfer of bacterial production to metazoa in benthic environments and Epstein et al. (1992) concluded that benthic ciliates from a temperate tidal beach of North American east coast feed mainly on flagellates.
A.H. bacterial abundance is inversely correlated with porosity. Bacterial abundance tends to be related to the total surface areas of particles (substratum available for bacteria) (Brown \& McLachlan 1990), which is in turn linked to the compactness of the sand and, therefore, under constant grain-size conditions, may be inversely related to porosity. It was not possible to identify any effect which porosity may have on the overall abundance of ciliates, but some taxa showed a clear preference for a narrow range of porosity values, suggesting that this parameter acts selectively.

The presence of macro- and meiobenthos (mainly small Bivalvia, small Polychaeta, Nematoda, and Copepoda) and of patched microorganisms (as shown here) could account for the interstitial oxygen spatial variations found. Moreover, the decomposition of organic matter may locally reduce oxygen content. Interstitial dissolved oxygen is generally considered to be a key factor in the distribution of interstitial protozoa but, in this study, a clear-cut relationship between this parameter and overall ciliate abundance was not found.

Taxonomic composition, dominance and (local) diversity change over small distances. These findings could lead to some different hypotheses: (1) microenvironments may differ at small distances and dominant species therefore change (Artemisio et al. 1991); (2) recolonization phases in different small areas of the sandy bottom may not be synchronized. Heterogeneity of cores may be further increased by different interspecific interactions during recolonization processes (Caswell \& Cohen 1991).

Acknowledgements. We are grateful to B. Finlay for his suggestions on a first draft of the manuscript and to Jodi Fener for her revision of the English text. This work was supported by a MURST $60 \%$ project of $G$. Santangelo.

\section{LITERATURE CITED}

Armitage P (1971) Statistical methods in medical research. Blackwell Sci Publ, Oxford

Artemisio JJ, Steward TA, Pickett STA, McDonnel MJ (1991) Spatial heterogeneity during succession: a cyclic model of invasion and exclusion. In: Kolasa J, Pickett STA (eds) Ecological heterogeneity. New York, Springer-Verlag, p 256-270

Bin S, Fleeger J, Carney RS (1993) Sediment microtopography and small-scale spatial distribution of meiofauna. J exp mar Biol Ecol 167:73-90

Brown AC, McLachlan A (1990) Ecology of sandy shores. Elsevier, Oxford

Buchanan JB (1984) Sediment analysis. In: Holme N, McIntyre AD (eds) Methods for the study of marine benthos, IBP Handbook 16. Blackwell Scientific Publications, Oxford, p 41-65

Carey P (1992) Marine interstitial ciliates. Chapman and Hall, London

Caswell H, Cohen JE (1991) Communities in patchy environ- 
ments: a model of disturbance, competition, heterogeneity. In: Kolasa J, Pickett STA (eds) Ecological heterogeneity. Springer-Verlag, New York, p 256-270

Chandler GT (1989) Foraminifera may structure meiobenthic communities. Oecologia 81:354-360

Corliss JO (1979) The ciliated Protozoa. Characterization, classification and guide to the literature. Pergamon Press, Oxford

Dragesco J (1960) Ciliés mesopsammique littoraux: systématique, morphologie, écologie. Trav Stat Biol Roscoff, Roscoff

Dragesco J (1965) Ciliés mésopsammique d'Afrique Noire. Cah Biol mar 6:357-399

Dragesco J, Dragesco-Kerneis A (1986) Ciliés libres de l'Afrique intertropicale. Introduction à la connaissance et à l'étude des Ciliés. Collection Faune Tropicale, XXVI, Editions de l'ORSTOM, Paris

Elliott JM (1977) Some methods for the statistical analysis of samples of benthic invertebrates. Amberside, UK, Freshwat Biol Ass Sci Publ

Epstein SS, Burkovsky IV, Shiaris MP (1992) Ciliate grazing on bacteria, flagellates and microalgae in a temperate zone sandy tidal flat: ingestion rates and food niche partitioning. J exp mar Biol Ecol 165:103-123

Fenchel T (1967) The ecology of marine microbenthos. I. The quantitative importance of ciliates as compared with metazoans in various types of sediments. Ophelia 4:121-137

Fenchel T (1968) The ecology of marine microbenthos. II. The food of marine benthic ciliates. Ophelia 5:73-121

Fenchel T (1969) The ecology of marine microbenthos. IV Structure and function of the benthic ecosystem, its chemical and physical factors and the microfauna communities with special reference to the ciliated protozoa. Ophelia 6 : $1-182$

Fenchel T (1987a) Ecology of Protozoa: the biology of freeliving phagotrophic protists. Science Tech Publisher, Madison, and Springer-Verlag, Berlin

Fenchel T (1987b) Ecology - potentials and limitations. In: Kinne $O$ (ed) Excellence in ecology, Vol 1. Ecology Institute, Oldendorf/Luhe

Fenchel T (1990) The role of protozoa in nature in terms of functional properties related to size. Zool Sci 7:51-58

Fenchel T, Finlay BJ (1991) The biology of free-living anaerobic ciliates. Eur J Protistol 26:201-215

Fenchel T, Finlay BJ, Gianni A (1989) Microaerophily in ciliates: responses of an Euplotes species (Hypotrichida) to oxygen tension. Arch Protistenkde 137:317-330
Finlay BJ, Clarke KJ, Vicente E, Miracle MR (1991) Anaerobic ciliate from a sulphide-rich solution lake in Spain. Eur J Protistol 27:148-159

Finlay BJ, Fenchel T, Gardner S (1986) Oxygen perception and $\mathrm{O}_{2}$ toxicity in the freshwater ciliated protozoan Loxodes. J Protozool 33:157-165

Giere O, Eleftheriou A, Murison DJ (1988) Abiotic factors. In: Higgins RP, Thiel $H$ (eds) Introduction to the study of meiofauna. Smithsonian Institution Press, London, $p$ $61-78$

Graf G (1989) Benthic-pelagic coupling in a deep-sea benthic community. Nature 341(6241):437-439

Kahl A (1930-1935) Urtiere oder Protozoa, I: Wimpertiere oder Ciliata (Infusoria), eine Bearbeitung der freilebenden und ecto-commensalen Infusorien der Erde, unter Ausschluß der marinen Tintinnidae. In: Dahl F (ed) Die Tierwelt Deutschlands. Fischer Verlag, Jena

Kemp PF (1988) Bacterivory by benthic ciliates: significance as a carbon source and impact on sediment bacteria. Mar Ecol Prog Ser 49:163-169

Lee JJ, Hutner SH, Bovee EC (1985) An illustrated guide to the protozoa. Society of Protozoologists, Lawrence

Legendre P. Troussellier M (1988) Aquatic heterotrophic bacteria: modelling in the presence of spatial autocorrelation. Limnol Oceanogr 33:1055-1067

Lucchesi P, Santangelo G (1992) Succession in interstitial ciliate communities. J Euk Microbiol 40:152A

Lucchesi P, Santangelo G (1993) Time behaviour of marine ciliates protozoa of sandy shores. In: 28th EMBS Symposium, Hersonissos, Crete, September 1993, p 21

Ricci N, Santangelo G, Luporini P (1982) Researches on the coast of Somalia. Sand-dwelling ciliates. Monit zool ital NS 4:115-148

Saburova MA. Polikarpov IG (1993) Spatial structure of microphytobenthos community of the soft sediments. In: 28th EMBS Symposium, Hersonissos, Crete, September 1993, p 42-43

Santangelo G, Lucchesi P (1992) The ciliated protozoa of an interstitial Mediterranean microcommunity. Hydrobiologia 230:79-92

Uhlig G (1964) Eine einfache Methode zur Extraktion der vagilen, mesopsammalen Mikrofauna. Helgoländer wiss Meeresunters 11:178-185

Verni F, Rosati G (1990) Peculiar epibionts in Euplotidium itoi (Ciliata, Hypotrichida). J Protozool 37:337-343

Wright JM (1983) Sand dwelling ciliates of South Wales. Cah Biol mar 24:187-214 